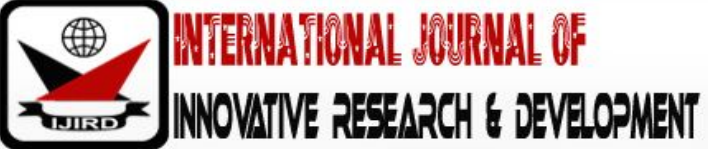

ISSN 2278 - 0211 (Online)

\section{The Nature of Transmigration Land Ownership and the Implementation of Regulation in the Province of West Sulawesi, Indonesia.}

\author{
Andi Hijrah Thalib \\ Post-Graduate Program, Doctoral of Legal Studies \\ Indonesia Muslim University of Makassar, Indonesia
}

\begin{abstract}
:
Land, as a gift of God Almighty, is a natural resource that is very needed by humans to meet their needs, both directly for their lives such as farming, or being used to live, or to carry out business activities such as places of industrial trade, agriculture, plantation, education construction of other facilities and infrastructure. The very limited empowerment of natural resources must be able to balance the growth rate of the rapidly human birth because all-natural resources, especially land, are not renewable. The natural religious relationship between human with land is a relationship of control and use of land in order to obtain benefits for the importance of life and livelihood, both for the importance of life and livelihood, both for their own interests as individual beings and shared interests as social beings. With such position, therefore land is the main resource which is a place for the interests of various parties, thus in reality there are various conflicts of interest above and below the ground, further more if the legal certainty of ownership is not established yet. Three years after the proclamation of independence, in 1948, the designing of the legal protection of national agrarian was begun. A special committee was formed in Yogyakarta because it was back then the capital of the country, then the legal protection in the land sector could finally be made, known as the birth of the Agrarian Principle Law (UUPA) which came into force on September 24, 1960.
\end{abstract}

Keywords: Land, transmigration, regulation, ownership

\section{Introduction}

In Law No. 6 year 1960 concerning the basic rules of agrarian matters (hereinafter, abbreviated as UUPA), it asserts that the earth, water, and space, and the natural resources contained within, are controlled by the state, and utilized as much as possible for the prosperity of the people. On the basis of mastering it, according to Abdurrahman ${ }^{1}$ in the UUPA, it has been determined that there are various kinds of land rights that can be given and owned by a person, both individually and jointly and a legal entity.

The right to control the land by the state comes from the inherent power of the state, which is reflected in the provisions of Article 33 (3) of the 1945 Republic of Indonesia's Constitution (hereinafter abbreviated as the UUDNRI 1945) which affirms that the earth and water and natural resources contained in it,are controlled by the state and used for the greatest prosperity of the people. The affirmation of Article 33 section (3) of the 1945 Constitution of the Republic of Indonesia is the main point of people's prosperity, because it must be controlled by the state and used for the greatest prosperity of the people. The statement explains two things, namely that constitutionally the state has a strong legalization to control land as part of the earth, but the control must be in the framework of the people's prosperity.

Further elaboration of the right to control the land by the state is contained in Article 2 paragraph (1) of the UUPA (Agrarian Principle Law) which determines that the earth, water and space, including natural resources contained in it at the highest level are controlled by the state, as an organization of power for all people. The right to control and the state authorizes the state to:

- Manage and organize the use, supply, and maintenance of earth, water, and space.

- Determine and manage the legal relationship between people and earth, water, and space.

- Determine and manage the legal relationship between people and legal actions related to earth, water, and space.

Based on the rules above, the concept of UUPA (Agrarian Principle Law) defines "being authorized" by state is not "being owned". Instead, it is defined as the rights allowing the state to manage those three rules. The state authority coming from the rights to control the natural resources is merely "public", meaning that the authority is to manage (regulation authority), and not the authority to dominate the land physically and to use the land as the authority of the rights of the land holder, which is said to be "private" (Muhamoel Bakri) 2 .

${ }^{1}$ Abdurrahman, Beberapa Aspek Tentang Hukum Agraria, Alumni of Bandung, 1985, pg.103

2 Muhammad Bakri, Hak Menguasai Tanah Oleh Negara (Paradigma Baru Untuk Reformasi Agraria), Citra Media, Yogyakarta, 2007 , pg.5 
The authorization of the state, in the context above, is the authorization that comes with responsibility, that is, people's prosperity. In other side, people also have the rights over the land. The property rights are hereditary, strong, and fulfilled in which these rights can go to people over the land, considering the social function of the land ownership. In other words, the relationship of individuals is legal relationship that leads to the rights and responsibility. Meanwhile, the relationship between the state and the land leads to authorization and responsibility.

In the region of the Republic of Indonesia consisting of a huge number of people, the distribution between natural carrying capacity and environmental capacity that has not been balanced yet will lead to social risk or environmental damage if it is not immediately overcome.

The uneven distribution of people creates tendency to live only in certain area, and the area, which is usually a developed area, will be increasing more. Conversely, region or area that has not been developed yet will be left behind. In the underdeveloped area or region, people are scattered in small groups that are difficult to develop. Thus, the distribution of people should be regulated through transmigration.

Transmigration, which is an integral part and national development, is any matters related to the preparation for an area in which people can live, do business, and be developed, as well as the activities of giving education or counseling toward people who do transmigration until the government take over them.

Transmigration will broaden and develop investment of business entities and people in utilizing the existing potential so that they can create wider and even job vacancies and business opportunity, as well as the development of region or area as the center of new economic growth. Therefore, transmigration will open an opportunity for people in another area to initiatively move and live the transmigration area in order to increase their prosperity. The emergence of economic center supports the development of the prosperity of the surrounding people.

Through transmigration as one of the forms of people mobility will face cultural meeting among groups in the society so that they need to de educated in order to accelerate the process of integration and acculturation, leading to strengthen the unity of people, leading to make Indonesia as a country that has synergic power in improving people's prosperity, developing regions, and strengthening national defense based on the insight of archipelago.

Transmigration is government's responsibility to pay attention to the development of values in the community so that their role will be supported in transmigration by giving them opportunity to enter business world and involving them as independent transmit grants from the aspect of employment and entrepreneurship. The qualifications of people that can be the participants of transmigration are:

- Troubled residents, who have the determination, and enthusiasm to increase welfare, but experience limitations in getting work and business.

- Populations that are relatively potential and have gained employment and business opportunities, but are willing to improve their welfare further.

- Residents, who have been able to develop themselves, but want to be better in improving their quality of life.

The three points above are then developed into three types of transmigration as follow:

- General transmigration is a type of transmigration that is fully organized by the government, whose transmigration receives assistance and, if necessary, receives subsidies from the government.

- Self-help transmigration is the type of transmigration designed by the government, working together with business entities as the transmigration business partners, while the government helps within certain limits to support, hence its partnerships become feasible.

- Self-reliant transmigration is a type of transmigration that is entirely a transmigration initiative carried out, both through collaboration with business entities and fully developed transmigration under the direction of the government.

Various transmigration main businesses developed including the main business activities of agriculture in the broad sense (primary business), industrial main business (secondary business), and service businesses and traders (tertiary businesses), those developed main businesses and types of commodities must be able to support each other in order to increase efficiency and productivity.

In this case, the acceleration, the acceleration of the improvement of the life of transmigration communities through the business partnership relationships with the business entities, should be developed and strengthened based on the relationships that are mutually beneficial, equitable, fair, transparent, and develop in a sustainable manner. Therefore, cooperatives need to be used as a forum for the economic development of transmigration communities based on kinship, cooperatives need to be developed from ground zero thus their existence is felt as a need and managed professionally then it can become the backbone of the economy and the development of transmigration businesses.

\section{Empirical Legal Research Methods}

There are two kinds of data sources for the empirical legal research:

- Primary data is the data obtained directly from the location of the research by a questionnaire or interview approach, this data is still raw data and will be processed to be presented in the form of a percentage table. In this connection, the sought data or the data regarding the implementation of the administration of land to the transmit grants as well as the data concerning what factors influence the implementation of land administration.

- Secondary data is the data relating to various documents obtained from transmigration agencies or other related agencies. 
The data written in this research from the results of the study of documents are analyzed qualitatively using normative juridical analysis methods to study the substance of the chairperson about the implementation or management and synchronization of sharing legislation provisions such as provisions or legislation program regarding both vertically and non-horizontally defense.

\section{Discussion}

The legal process of land acquisition for the transmigration towards the state land according to the procedure is that if the land is in the form of forest, it must be released from the exploitation of the forest firstly. While the mechanism for the procurement of land for transmigration from customary/ individual lands, according to the procedure must be through the release or remission of land rights from the rightful owner by providing appropriate compensation or appropriate compensation (recognition).

Broadly speaking, the establishment and utilization of land at transmigration location, according to the regulations of the Directorate General of Agrarian Affairs and Transmigration No. 3 of 1967,are as follow:

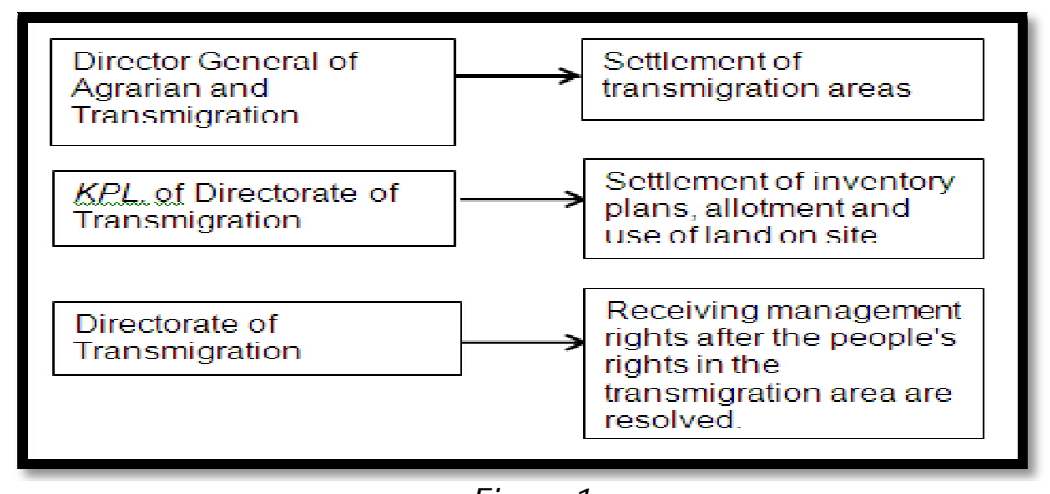

Figure 1

Regulation of the Director General of Agrarian Affairs and Transmigration Number 3 of 1967 explicitly regulates matters concerning land granted to the transmigration family heads. The obtained rights are 2 ha per family head, this land area is used for housings and agricultural businesses with rights to use.

The conditions for granting these rights must be fulfilled by the recipient of the right, namely:

- The provided land must be actively cultivated by the concerned transmigration.

- The concerned transmigration family must reside on that land.

- All actions in any form as well as including transferring or surrendering to others to use or binding them as collateral for debt, are prohibited and becoming total for the sake of the law.

- If the concerned transmigration family head passes away, then the land use can be continued by his/her heirs provided that within 6 months of the head family's death, the heirs must declare their wishes to that official.

- Violations of the conditions that must be fulfilled can be used as an excuse to revoke the rights to the concerned person.

The prohibition on any form of transfer of local transmigration land is found on the Director General of Transmigration Decree Number: 003/Inst/Trans/1975 concerning the supervision and handling of the land for transmigration as well as regulating the provisions of transmigration land.

Provision and preparation of land for transmigration settlements thoroughly, according to Sumantri (1979: 612-623), include three (3) stages as follow:

- Stage of area preparation

- Stage of mapping/ spatial layout

- Stage of measurement

The information and the main data are presented in the transmigration development guidance board to make decision. The result of decision is the base, and the Governor writes a letter to choose a location for transmigration project. After then, the Governor writes a letter of choosing the area of transmigration to be conducted a research to obtain general description of the research in that area. The research covers:

- General identification to obtain:

- Boundaries and areas that are planned

- $\quad$ Land use of the areas that are planned

- The quality of area

- $\quad$ Climate and water system

- $\quad$ Accessibility of the planned project and its development

- $\quad$ Problem of the land status as well as another consideration in social, economic, and defense and security fields.

- $\quad$ Land capability

- $\quad$ Agriculture plan 
If the land has been taken over by local people or the community of custom, the land should be freed first in which the procedure is written in the regulation of the Ministry of Domestic Affairs through the head of Sub Directorate of Agriculture of the local district or National Land Agency (Badan Pertahanan Nasional or BPN). After then, the process continues to the Directorate of Agriculture of the province and to the department of Domestic Affairs Cg Directorate General of Agriculture in order to get the rights of ownership. Thus, there will be security of legal land ownership so that the land clearing will run smoothly. After the residence areas have been available, the process goes to the development of residence. During this process, it is necessary to have cooperation between Department of Public Works Cg Bina Margaand Department of Agriculture. Department of Agriculture should give consideration on the land clearing in order to maintain its fertility. This is based on the regulation on Article 15 of UUPA Number 5 of 1960 stating that:

"Cultivating the land, including developing the land fertility as well as to prevent the damage becomes the responsibility of each person, legal entity, or instance that has legal relation with the and by paying attention to the weak economic party"

The next step is making physical suggestion in the form of roads, irrigation, land clearing for yard, field, farming area, and soon. After all physical means have been ready, all transmigrants are invited to the location of transmigration, based on the regulation Number 15 of 1997.

"Transmigrants have the right to get land and yard and or farmland with the rights over the land according to the applied terms and conditions"

Related to the implementation of the regulation of Number 15 of 1997, then in Number 2 of 1999, the land allocation for the transmigrants is strengthened, consisting of:

- Farmer transmigrants have the rights to get at least 2 Ha of land to be used as:

- 0.25 Ha is used for housing and yard

- 1.75 Ha is used for housing, yard, and or farming area

- Transmigrants, who are not farmers, have the rights to get 0.25 Ha of land used for housing and yard.

The regulation above concerning on the allocation of land to all transmigrants is based on the terms and conditions on agriculture about the minimum limit of agriculture land so that it does not harm public interest, then the land ownership belonging to and being authorized by a person or legal entity is limited. According to the regulation Number 56 of 1960 concerning on the determination of farming area, it is said that the minimum farming area is $2 \mathrm{Ha}$, for both wet and dry farming area.

Transmigration is a system of transferring population from a densely populated area. During the implementation of transmigration, the government makes a regulation that becomes the base of its implementation in West Sulawesi.

West Sulawesi located in eastern Indonesia is known as transmigration area and relatively has got much attention, especially about the ownership of the transmigration land. West Sulawesi comes with its own social condition, along with its local wisdom which is still maintained, including pride in terms of land ownership.

In West Sulawesi,District of Mamuju and Central Mamuju, transmigration is considered successful in implementing the transmigration program.

With the above considerations, Province of West Sulawesi can be seen specifically as follows:

- The Province of West Sulawesi has been a recipient of transmigrants since it was still termed colonization in the District of Polewali Mandar (Polman).

- The Districts of Mamuju and Central Mamuju in the Province of West Sulawesi have become remote transmigration sites before becoming the Province of West Sulawesi / having separated of the Province of South Sulawesi since 2004.

- The Districts of Mamuju and Central Mamuju are the trans road of Sulawesi which are considered to be the connecting areas among provinces on the island of Sulawesi.

\section{Conclusion}

Based on the description and discussion of the problem in this article, then the conclusions are:

- Various developed main businesses transmigration including the main business activities of agriculture in the broad sense (primary business), industrial main business (secondary business), and service businesses and traders (tertiary businesses), these developed main businesses and types of commodities must support each other therefore it can increase efficiency and productivity.

- That Province of West Sulawesi is characterized by the social condition of the community with local wisdom which is always maintained including self-esteem in matters of ownership rights to land.

- Regarding the implementation of Law Number 15 of 1997, then in Number 2 of 1999, it is reaffirmed regarding the distribution of land / land allotments according to their designation.

\section{References}

i. Adrian Sutedi, 2017, Peralihan Hak Atas Tanah. Penerbit Sinar Grafika : Jakarta.

ii. Abdullah, R., 2000. Pelaksanaan Otonomi Luas dan Isu Federalisme Sebagai Suatu Alternatif.Penerbit PT Raja Grafindo Persada, Jakarta.

iii. Anonim, 1999. Garis-Garis Besar Haluan Negara (GBHN) Tahun 1998-2003. Penerbit Sinar Grafika, Jakarta.

iv. Arrasyid, Ch., 2000. Dasar-Dasar llmu Hukum. Penerbit Sinar Grafika, Jakarta.

v. Ashshofa, B., 1996. Metode Penelitian Hukum. Penerbit Rineka Cipta, Jakarta.

vi. Attamimi, S.A. Hamid, Indrati Soeprapto, M.F., 1998. llmu Perundang-Undangan, Dasar-Dasar dan Pembentukannya. Penerbit Kanisius, Yogyakarta. 
vii. Bambang Sunggono, 1994. Hukum, Lingkungan dan Dinamika Kependudukan. Penerbit PT Citra Aditya Bakti, Bandung.

viii. C. A. Sanchez, 1982. Pendidikan Kependudukan. Penerbit Bumi Aksara, Jakarta.

ix. Erwiningsih, W., 2000. Aktualisasi Hukum Agraria Guna Menunjang Otonomi Daerah. Jurnal Hukum Universitas Islam Indonesia, Yogyakarta. Nomor 13, halaman 84 - 86.

x. Friedman, M.D.A., 1974. The Legal Structure. Longman Group Limited.

xi. Friedman, L, 1975. The Legal System, A Social Science Perspective. New York, Russell Save Foundation.

xii. Hadjon, Ph.,M., 1987. Perlindungan Hukum Bagi Rakyat di Indonesia. Penerbit PT Bina llmu, Surabaya.

xiii. Hamzah, A., 1991. Hukum Pertanahan di Indonesia. Penerbit Rineka Cipta, Jakarta.

xiv. Lawrence M., Friedman, 2001. American Law and Introduction. Penerbit PT Tata Nusa, Jakarta.

xv. Poerwadarminta, W.1S, 1982. Kamus Umum Bahasa Indonesia. Penerbit PN Balai Pustaka, Jakarta. 